BIOMEDICAL AND BIOSOCIAL ANTHROPOLOGY
$\begin{gathered}\text { Official Journal of the International Academy } \\ \text { of Integrative Anthropology } \\ \text { journal homepage: http://bba-journal.com }\end{gathered}$

\title{
Study of morphological changes in the kidney during modeling of ischemic-reperfusion injuries of the limb and massive blood loss
}

Volotovska N. V.

I. Ya. Horbachevsky Ternopil National Medical University, Ternopil, Ukraine

\section{ARTICLE INFO}

Received: 21 October 2020

Accepted: 24 November 2020

UDC: $616.61: 616.748-005.1 / .4]-092.9$

\section{CORRESPONDING AUTHOR}

e-mail: volotovskanv@tdmu.edu.ua Volotovska N. V.
The article presents the features of morphological disorders of liver tissue on the background of limb ischemia-reperfusion and massive blood loss. The aim of the work was to establish the presence of structural changes and the severity of morphological disorders of internal organs, remote from the primary place of ischemia-reperfusion during modeling the pathological process. The experiment was performed on 33 adult nonlinear white rats weighing 200-250 g, which were on the standard vivarium diet. Experimental animals were simulated with ischemic-reperfusion syndrome of the lower extremity and massive blood loss. Collection of materials was performed $1 \mathrm{~h}$ after intervention or release from the tourniquet and on the 1st, 3rd, 7th and 14th days. All interventions were performed under thiopental-sodium anesthesia $(40 \mathrm{mg} / \mathrm{kg}$ body weight). Mostly structural violations were expressed as disturbance of blood supply of little and middle caliber blood vessels and also in initial dystrophic changes. During comparison of groups, depending on the severity, it was shown that both the isolated use of a tourniquet and massive blood loss had long-term, systemic consequences, however, more expressed in EG-2; single vascular glomeruli were shrunked, endothelial cells of arterioles were slightly damaged. On the 7th and 14th days changes in the structure of EG-1 were mostly absent, although in EG-2 the epitheliocytes of the outer layer of the capsule remained flattened, retained full blood vessels of the venous bed in the interstitium, and the vast majority of epitheliocytes of the excretory tubules were at different stages of hydropic dystrophy with partly desquamation of the epithelium in the gaps of the tubules. Also, the basal membranes of the tubules were not completely visualized, which indicates deep damage in the structures caused by acute ischemia as a result of bleeding. Thus, as combat trauma (blood loss) is in itself a life-threatening factor, the use of a tourniquet due to the development of ischemic-reperfusion process can complicate the course of the primary affection. Knowledge of the periodization of traumatic disease on the background of this pathology is important for the development of sanogenic effects in order to minimize this pathogenic factor.

Key words: hemostatic tourniquet, kidney, experiment, ischemic-reperfusion syndrome, blood loss).

\section{Introduction}

The use of a tourniquet is still an important first aid measure [11, 13]. Active battles that occur periodically in the modern world, including in Ukraine, are accompanied with injuries and blood loss and require careful study of the mechanisms of posttraumatic period. A significant role of ischemic-reperfusion syndrome due to the use of tourniquet now is actively discussed [1,9]. There are materials in the literature that highlight the ambiguity of reperfusion changes as a result use of a tourniquet.

The pathogenesis of the process is based not only on hemic hypoxia, but also on the combination of its consequences with manifestations of rhabdomyolysis and massive entry into the systemic bloodstream of products of lipid and protein peroxidation from exsanguinated tissues [4]. The morphological changes of skeletal muscles that were under pressure of the tourniquet were best studied [18]; they consisted of dystrophic changes in muscle fibers and were apparently caused by a violation of ionic composition, an imbalance of metabolic processes due to a shift in acid-base balance on the background of tissue hypoxia. In particular, the structural changes of the soft tissues of the extremities and modifications in the 
microcirculatory tract $[10,15,22]$ on the background of this syndrome were studied.

There are morphologically confirmed data about lungs changes on the background of modeling ischemic and reperfusion injuries of the limb [19]; however, in this case the ischemia lasted 4 hours and led to a significant disturbance in the microcirculatory tract without signs of an inflammatory reaction. In the reperfusion stage morphological changes were found. It corresponded to the expression of the second phase of respiratory distress syndrome; changes in the structure of the large joints of the lower extremities were also recorded in conditions of combined abdominal and skeletal trauma in combination with ischemia-reperfusion [14].

The consequences of massive blood loss in accordance to the statistics, study of the ambiguous effects of limb ischemia-reperfusion with the next use of tourniquet has particular importance - as the release of biologically active substances from endothelial cells, cytokine storm, which may have systemic effects. However, these aspects are still not enough studied.

The aim of the work was to establish the presence of structural changes and the severity of morphological disorders of the tissues of internal organ, remote from the primary place of ischemia-reperfusion during modeling the pathological process.

\section{Materials and methods}

The experimental study was performed on 33 adult nonlinear white male rats weighing 200-250 g, which were on the standard mode of keeping the vivarium. Animals were divided into 3 groups: EG-1 - the use of a tourniquet on the thigh for $2 \mathrm{~h}$ (isolated ischemia-reperfusion); EG-2 simulation of blood loss and control group.

The interventions were performed under conditions of thiopental-sodium anesthesia $(40 \mathrm{mg} / \mathrm{kg})$ in consideration with the rules of the "European Convention for the Protection of Vertebrate Animals Used for Experimental and Other Scientific Purposes" (European Convention, 1984) and Law of the Ministry of Health of Ukraine № 690, considered by the commission at a meeting of the commission on bioethics of I. Ya. Gorbachevsky Ternopil National Medical University of the Ministry of Health of Ukraine № 61 by 11.01.2020.

In EG1 animal were simulated with ischemiareperfusion of the limb. Under thiopental-sodium anesthesia (40 $\mathrm{mg} / \mathrm{kg}$ body weight intraperitoneal), SWAT$\mathrm{T}$ (US) tourniquet with width $10 \mathrm{~mm}$ was applied to the thigh of an animal and adequately corresponds pressure of the tourniquet when applied to the thigh of an adult human. According to the literature, such a tourniquet is characterized by minimal negative traumatic effects on the underlying tissues due to its width and long-term pain threshold. The tourniquet was tightened according to the applied effective pressure marking, which is able to stop the blood flow. In EG2 under conditions of anesthesia, acute heavy blood loss (up to $40 \%$ of volume of circulating blood) was modeled by puncture of the femoral vein with farther hemostasis.

The morphological study of tissue sections of the kidney was performed and documented according to the generally accepted method with hematoxylin-eosin staining using a LOMO Biolam I microscope.

\section{Results}

Histological examination of the animals' kidneys (in EG1) on the 1st day after the intervention on the background of isolated use of a tourniquet revealed uneven blood supply to the organ with mostly reduced blood supply to the cortical layer and partial hyperemia of the medullar layer (Fig. 1).

The size of the glomeruli decreased, their lumens narrowed due to decreased blood supply or spasms. The structure of the glomeruli remained mostly preserved, the nephrothelium of the inner layer of the capsule shrunked slightly. The stroma of the organ was weakly visualized. Manifestations of edema in the interstitium were not observed. In the vast majority of excretory tubules, the renal lumen did not dilate and was not clearly visualized. Manifestations of changes in epitheliocytes were not expressed.

Histological examination of the animals' kidneys on the 7th day of the experiment revealed, as in the previous stage, uneven blood supply to the organ with mostly reduced blood supply of the cortical layer and partial hyperemia of the medullar layer (Fig. 2).

The size of the glomeruli remained reduced due to the reduced blood supply in the vessels, the structure of the glomeruli remained mostly preserved, and the lumens of single vessels partially expanded. The lumens of some glomeruli expanded moderately, the nephrothelium

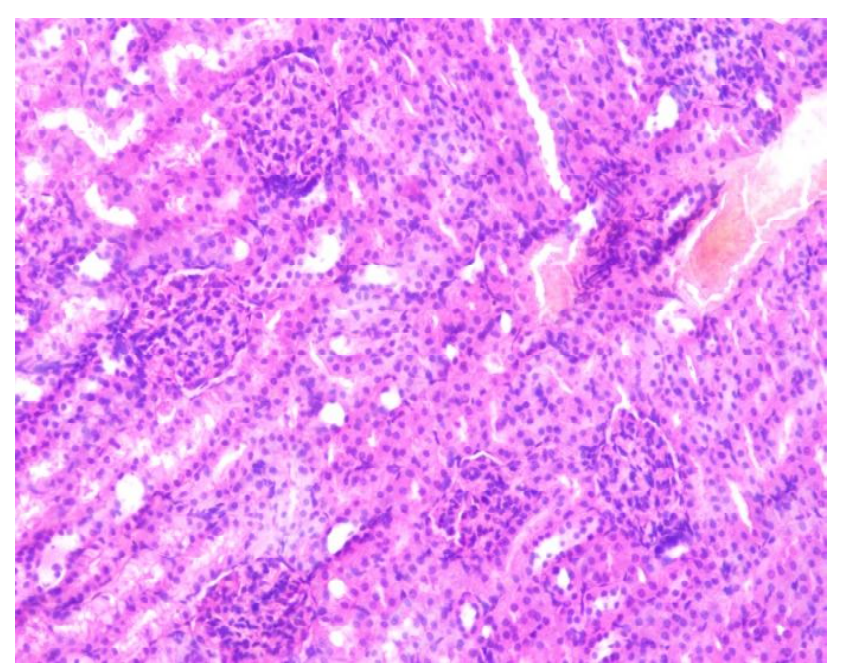

Fig. 1. The structure of the kidney on the 1 st day after modeling of ischemia. Spasms of the vessels of the glomerular layer, decreased blood supply in the vessels of the cortical layer, narrowing of the lumen of the capsule. Staining with hematoxylin and eosin. $x 200$. 


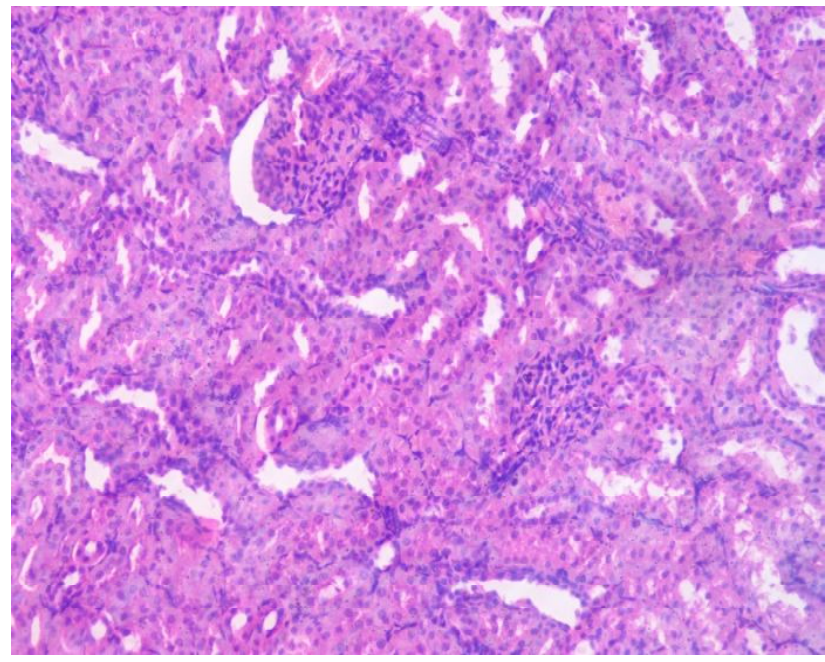

Fig. 2. The structure of the kidney on the 7th day after modeling ischemia. Reduced blood supply in the vessels of the glomeruli. Hematoxylin and eosin staining. $x 200$.

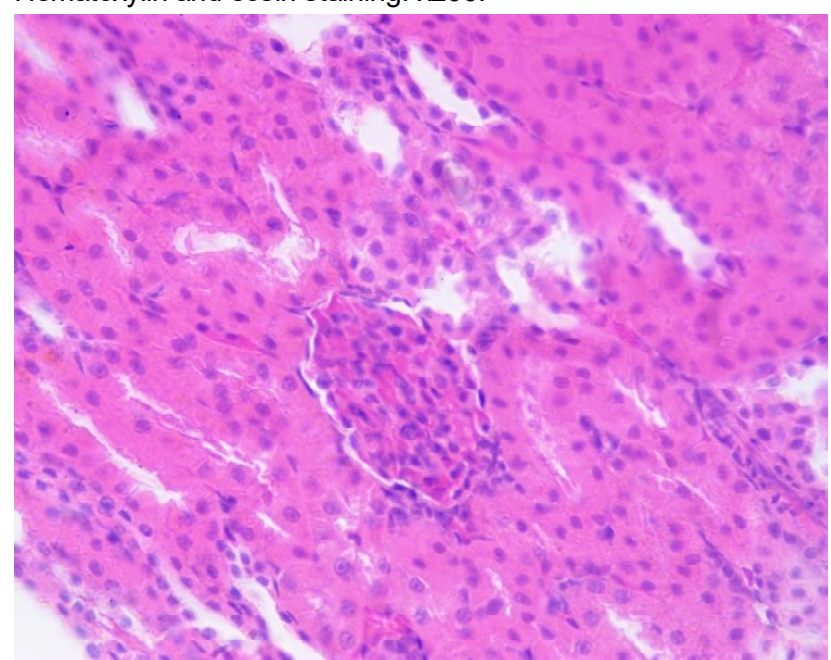

Fig. 3. The structure of the kidney on the 14th day after the simulation of ischemia. Equable blood supply of glomerular vessels, epithelium of excretory tubules without visible changes. Staining with hematoxylin and eosin. $x 200$.

remained flattened. The stroma of the organ was poorly visible. Manifestations of edema in the interstitium were not observed. The vessels of the predominantly venous layer were visualized to be moderately dilated and fullblooded, but perivascular edema was absent. In several of the excretory tubules the lumens expanded moderately, some contained fibrinous layers. Manifestations of changes in epitheliocytes remained minimal.

Histological examination of the animals' kidneys of animals on the 14th day of the experiment revealed the restoration of blood supply in the vessels of both the cortical and medullar layers. The size of the glomeruli was increased, and vessels with moderate blood supply were well visualized. The lumens of the glomeruli had a normal structure, the structure of the nephrothelium was restored. Manifestations of edema in the interstitium were not observed. In the interstitium of the medullar layer, the vessels had a equable blood supply, perivascular edema was not observed. The lumens of the excretory tubules remained normal. Manifestations of changes in epitheliocytes remained minimal (Fig. 3).

Histological examination of the kidney in EG-2, on the background of modeling of isolated massive blood loss on the 3rd day after the intervention revealed reduced blood supply in the cortical and cerebral matter. The structure of the glomeruli remained predominantly preserved, the blood supply of the vessels of several glomeruli decreased, single vascular glomeruli were shrunked and endothelial cells of arterioles were slightly damaged. The lumens of the capsule slightly expanded. The epitheliocytes of the outer layers of the capsule shrunked, but were visualized in almost all glomeruli.

In the interstitium, the lumens of the vessels of the venous bed slightly expanded. The structure of a small number of epitheliocytes of the excretory tubules had different stages of development of protein dystrophy, in a some of them signs of apoptosis were present. Nuclei were visualized in the vast majority of cells, some of which were hyperchromic, with the presence of nucleoli, located basally, intercellular contacts remained mostly preserved. The lumens of the vast majority of excretory tubules were slightly dilated, containing minimal inclusions (Fig. 4).

Examination of the kidneys on the 7 th day after the experiment revealed a moderate increase in blood supply of the cortical and medullar matter. The structure of the glomeruli remained mostly preserved, the blood supply of the vessels of some glomeruli increased significantly, the size of the vascular glomeruli increased. Some endothelial cells were lost. The lumens of the capsule were practically not visualized. The epitheliocytes of the outer layer of the capsule were moderately flattened.

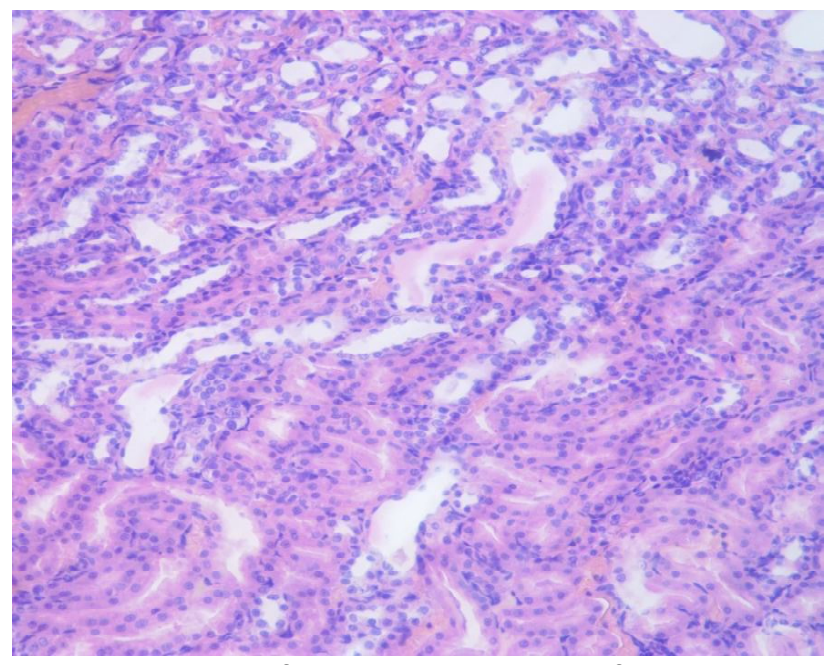

Fig. 4. The structure of the kidney on the 3 rd day after the simulation of bleeding. Reduced blood supply in blood vessels, areas of expansion of the excretory tubules. Staining with hematoxylin and eosin. $x 200$. 


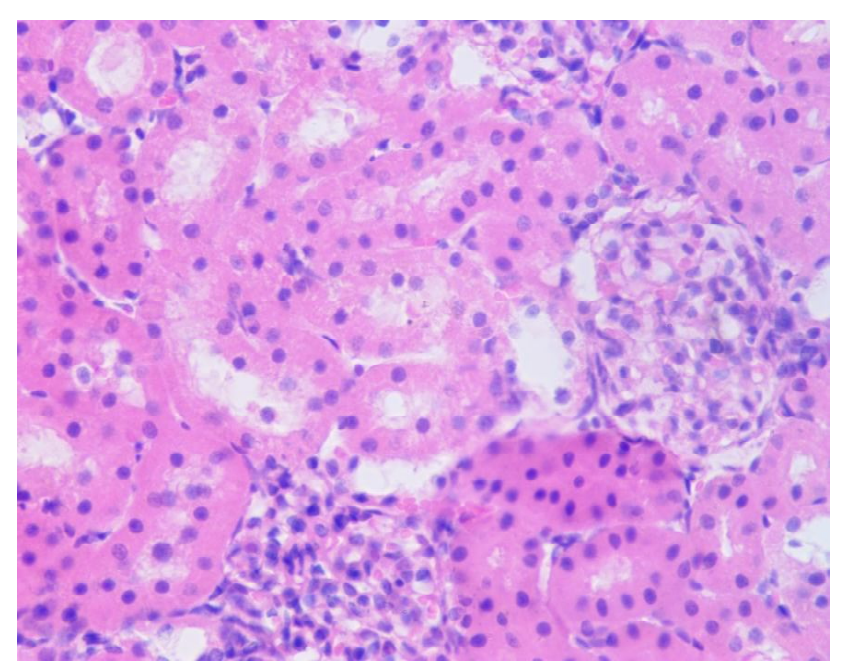

Fig. 5. The structure of the kidney on the 7 th day after the simulation of bleeding. Dystrophic-necrotic changes of epitheliocytes of excretory tubules, partial damage of basal membranes. Hematoxylin and eosin staining. $x 400$.

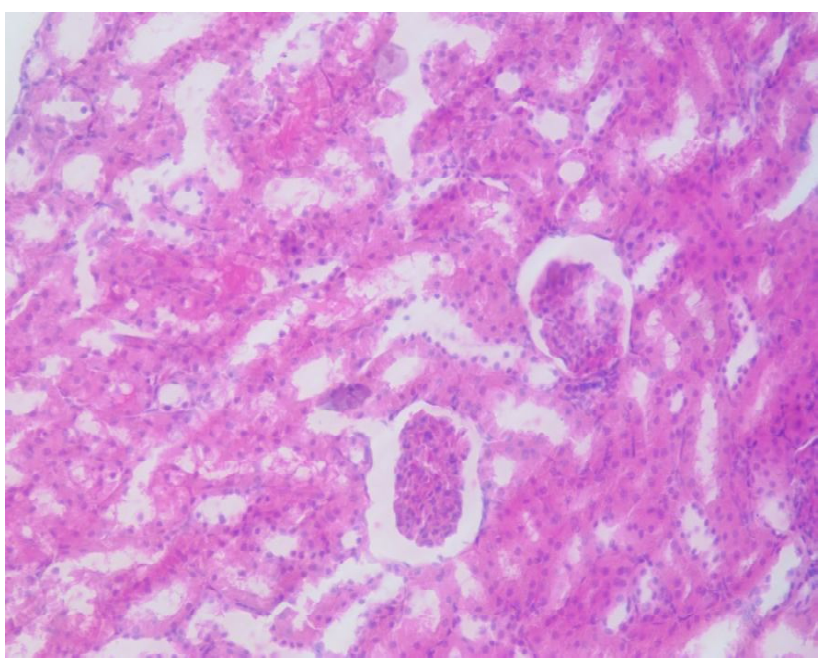

Fig. 6. The structure of the kidney on the 14th day after the simulation of bleeding. Hydropic dystrophy of epitheliocytes of excretory tubules, damage of basal membranes, wrinkling of vascular glomeruli. Staining with hematoxylin and eosin. $x 200$.

In the interstitium, the lumens of the vessels of the venous bed were moderately dilated, somewhere fullblooded. The structure of the vast majority of epitheliocytes of the excretory tubules had different stages of development of protein dystrophy, some of them were with signs of apoptosis. Nuclei were visualized in the vast majority of cells, but their location was different. The cytoplasm of a large part of the cells became granular or enlightened, the cell nuclei were lost, which indicates the development of dystrophic-necrotic changes. The basal membranes of the tubules were partially damaged (Fig. 5). The lumens of the vast majority of excretory tubules were slightly dilated, containing fragments of cellular structures.

Examination of the kidneys on the 14th day after the experiment revealed a moderate increase in blood supply in the cortical and medullar matter. The glomeruli shrunked, the blood supply of the vessels of single glomeruli decreased, the size of the vascular glomeruli was not changed. Some endothelial cells remained lost. The lumens of the capsule were expanded. The epitheliocytes of the outer layer of the capsule remained flattened.

In the interstitium, the lumens of the vessels of the venous bed remained full-blooded. The vast majority of epitheliocytes of the excretory tubules were at different stages of development of hydropic dystrophy with focal desquamation of the epithelium in the tubules gaps. The basal membranes of the tubules were not partially visualized, which indicates deep damage to the structures caused by acute ischemia due to bleeding. Nuclei were visualized in the vast majority of cells, but their location, as in the previous group of studies, was different. The cytoplasm of a large part of the cells was homogeneous, homogeneous, a significant part of the basement membranes remained preserved (Fig. 6). The lumens of a large part of the excretory tubules remained dilated, containing fragments of cell membranes.

\section{Discussion}

Undoubtedly, the involvement of each organ in the realization of the consequences of local ischemiareperfusion has its own characteristics and is now being actively studied by scientists in all around the world. In the conditions of wide variety of types of operations, tourniquet is actively used in arthroplasty [17], before restoration of blood supply to internal organs or limbs after transplantation [16]. And a special place among them is occupied by ischemia-reperfusion of the limb due to the use of hemostatic tourniquet in combat injuries [12].

Applying a tourniquet to any part of the body - whether in surgery on the heart or a wounded vessel of the limb, and release from it has a number of similar pathogenetic mechanisms. This is hypoxia of the tissue due to stop of its normal blood supply [24], the pressure of the tourniquet on the vessel (ligature) or subordinate tissues, so the complications, respectively, are both local and remote [6, 23]. Due to the bleeding of this area, hypoxia develops first with following generation of reactive oxygen species [7]. This causes "oxidative stress" as a manifestation of an imbalance between antioxidant defense systems and the activity of oxidants. Thus, based on the fact that in the reperfusion syndrome there are two stages - the local response, which follows the reperfusion and is manifested by swelling of the limb, followed by the development of local damage; and systemic damage, which is manifested by multiorgan affection. Physiological and anatomical studies confirm that the most brightly changes, in particular irreversible damage to muscle cells, begin after 3 hours of ischemia [3] and expressed as microvascular damage. At local compression of tissues of an extremity with a hemostatic tourniquet muscle damage appear. After that accumulation of myoglobin in plasma eventually becomes one of the factors causing toxic 
necrosis of tubular epithelium, provoking development of myoglobinuric nephrosis and acute renal failure which, as usual, up to the $9-12^{\text {th }}$ day results in the restoration of renal function [20].

The intensity of the inflammatory response has both local and systemic effects, which are a consequence of pathophysiological, biochemical and immunological changes that occur in ischemic-reperfusion periods. And despite the fact that there are certain features of the development of consequences in the heart, brain, extremities in diabetes or organs after transplantation or use of hemostatic jute, but the essence of the mechanisms remains the same: [8] active oxygen and active neutrophils are one of the main effectors, responsible for the development of local and systemic damage. A paradox is realized in the mechanism of reperfusion injury: the lack of oxygen is detrimental to the normal functioning of cells. Reperfusion, instead of normalizing metabolism, initiates an inflammatory response that can either enhance the local tissue response or stop further organ damage. Polymorphonuclear neutrophils that migrate to distant organs due to ischemia-reperfusion release lipid mediators, including leukotriene B4, cysteinyl-LTs, platelet activating factor that triggers inflammation in response [2].

Thus, summarizing the written above, the cellular damage that occurs in the reperfusion phase may be either

\section{References}

[1] Ardasheva, E. I., Razumov, P. S., \& Dolgova, S. G. (2004). Влияние перфторана на процессы перекисного окисления липидов в головном мозге и мягких тканях крыс при тяжелой компрессионной травме [Effect of perfluorane on lipid peroxidation processes in the brain and soft tissues of rats with severe compression injury]. Биомедицинский журнал - Biomedical Journal, (5), 151-153.

[2] Bitencourt, C. S., Bessi, V. L., Huynh, D. N., Menard, L., Lefebvre, J. S., Levesque, T., ... \& Marleau, S. (2013). Cooperative role of endogenous leucotrienes and platelet-activating factor in ischaemia-reperfusion-mediated tissue injury. Journal of cellular and molecular medicine, 17(12), 1554-1565. doi: 10.1111/jcmm. 12118

[3] Blaisdell, F. W. (2002). The pathophysiology of skeletal muscle ischemia and the reperfusion syndrome: a review. Cardiovascular Surgery, 10(6), 620-630. doi: 10.1016/s09672109(02)00070-4

[4] Burianov, O. A., Strafun, S. S., Laksha, A. M., Yarmoliuk, Yu. O., Mazevych, V. B., \& Lykhodii, V. V. (2014). Вогнепальні поранення кінцівок: Методичні рекомендації [Gunshot wounds of the extremities: Methodical recommendations]. K., 2014.

[5] De Groot, H., \& Rauen, U. (2007). Ischemia-Reperfusion Injury: Processes in Pathogenetic Networks: A Review. In Transplantation proceedings (Vol. 39, No. 2, pp. 481-484). Elsevier. doi: 10.1016/j.transproceed.2006.12.012

[6] Ergün, Y, Üremiş, M., Kilinç, M., \& Alici T. (2016). Antioxidant effect of Legalon(r) SIL in ischemia-reperfusion injury of rat skeletal muscle. Acta Cirúrgica Brasileira, 31(4), 264-270. doi: 10.1590/S0102-865020160040000007

[7] Ferrari, R. S., \& Andrade, S. F. (2015). Oxidative Stress and Lung Ischemia-Reperfusion Injury. Oxidative Medicine and Cellular Longevity, 2015. doi: 10.1155/2015/590987 a consequence of cell damage that has already occurred in the ischemic stage, or a consequence of the inflammatory response. Intracellular damage - in part may be the same as oxygen-free cell damage. In addition, activation of intracellular signaling cascades and apoptotic mechanisms is commonly discussed [5, 21].

\section{Conclusions}

Comparison of groups depending on the severity showed that both the isolated use of a tourniquet and massive blood loss had long-term, systemic consequences, however, more expressed in EG-2. The main changes consisted of heterogeneous blood supply in small and medium-sized vessels; single vascular glomeruli shrunked, endothelial cells of arterioles were slightly damaged. On the 7th and 14th days changes in the structure of EG-1 were mostly absent, although in EG-2 the epitheliocytes of the outer layer of the capsule remained flattened, retained full blood vessels of the venous bed in the interstitium, and the vast majority of epitheliocytes of the excretory tubules were at different stages of hydropic dystrophy with partly desquamation of the epithelium into the gaps of the tubules. Also, the basal membranes of the tubules were not completely visualized, which indicates deep damage in the structures caused by acute ischemia next to the bleeding.

[8] Gillani, S., Cao, J., Suzuki, T., \& Hak, D. J. (2012). The effect of ischemia reperfusion injury on skeletal muscle. Injury, 43(6), 670-675. doi: 10.1016/j.injury.2011.03.008

[9] Henyk, S. M., \& Symchych, A. V. (2016). Реперфузійний синдром після реваскуляризації ішемії нижніх кінцівок [Reperfusion syndrome after revascularization of lower extremity ischemia]. Серце і судини - Heart and blood vessels, (3), 104-108.

[10] Howell, N. J., \& Tennant, D. A. (2014). The role of HIFs in ischemia-reperfusion injury. Hypoxia, (2), 107-111. doi: 10.2147/HP.S49720

[11] Inaba, K., Siboni, S., Resnick, S., Zhu, J., Wong, M. D., Haltmeier, T., ... \& Demetriades, D. (2015). Tourniquet use for civilian extremity trauma. Journal of Trauma and Acute Care Surgery, 79(2), 232-237. doi: 10.1097/TA.0000000000000747

[12] Kauvar, D. S., Baer, D. G., Dubick, M. A., \& Walters, T. J. (2006). Effect of fluid resuscitation on acute skeletal muscle ischemia-reperfusion injury after hemorrhagic shock in rats. Journal of the American College of Surgeons, 202(6), 888896. doi: 10.1016/j.jamcollsurg.2006.03.003

[13] Kauvar, D. S., Dubick, M. A., Walters, T. J., \& Kragh Jr, J. F. (2018). Systematic review of prehospital tourniquet use in civilian limb trauma. Journal of trauma and acute care surgery, 84(5), 819-825. doi: 10.1097/TA.0000000000001826

[14] Kryliuk, V. O., \& Hariian, S. V. (2019). Вплив ішемії-реперфузії на морфологічні зміни великих суглобів нижніх кінцівок за умов поєднаної абдоміно-скелетної травми [Influence of ischemia-reperfusion on morphological changes of large joints of the lower extremities under the conditions of combined abdominal and skeletal trauma]. Експериментальна і клінічна медицина - Experimental and clinical medicine, 85(4), 4-8. doi: 10.35339/ekm.2019.85.04.01 
[15] Kutepov, D. E., Zhigalova, M. S., \& Pasechnik, I. N. (2018). Патогенез синдрома ишемии-реперфузии [Pathogenesis of ischemia-reperfusion syndrome]. Казанский медицинский журнал - Kazan Medical Journal, 99(4), 640-644. doi: 10.17816/KMJ2018-640

[16] Laubach, V. E., \& Sharma, A. K. (2016). Mechanisms of lung ischemia-reperfusion injury. Current opinion in organ transplantation, 21(3), 246. doi: 10.1097/ MOT.0000000000000304

[17] Leurcharusmee, P., Sawaddiruk, P., Punjasawadwong, Y., Chattipakorn, N., \& Chattipakorn, S. C. (2018). The Possible Pathophysiological Outcomes and Mechanisms of Tourniquet-Induced Ischemia-Reperfusion Injury during Total Knee Arthroplasty. Oxidative Medicine and Cellular Longevity, 2018. doi: $10.1155 / 2018 / 8087598$

[18] Pedowitz, R. A. (1991). Tourniquet-induced neuromuscular injury. A recent review of rabbit and clinical experiments. Acta Orthopaedica Scandinavica, 62(sup245), 1-33. PMID: 1950503

[19] Sergiyenko, V. I., Petrosyan, E. A., Onopriyev, V. I., \& Laypanov, Kh. Kh. (2006). Морфологические изменения легких при моделировании и лечении ишемических и реперфузионных повреждений конечности [Morphological changes in the lungs during modeling and treatment of ischemic and reperfusion injuries of the limb]. Общая реаниматология General resuscitation, 2(5-6), 129-132.

[20] Sheiko, V. D., Panasenko, S. I., \& Chelishvili, A. L. (2019). Хірургія надзвичайних ситуацій - навчальний посібник [Emergency surgery - a textbook]. Полтава: Астрая, 2019 Poltava: Astraya, 2019.

[21] Teoh, N. C., \& Farrell, G. C. (2003). Hepatic ischemia reperfusion injury: Pathogenic mechanisms and basis for hepatoprotection. Journal of Gastroenterology and Hepatology, 18(8), 891-902. doi: 10.1046/j.1440-1746.2003.03056.x

[22] Walters, T. J., Gang, K., \& Corona, B. T. (2015). Activity attenuates skeletal muscle fiber demage after ischemia and reperfusion. Muscle Nerve, 52(4), 640-648. doi: 10.1002/ mus. 24581

[23] Whatling, P. J., \& Galland, R. B. (1999). Isolated Compartment Syndrome of the Hand After Brachial Embolectomy. European Journal of Vascular and Endovascular Surgery, 17(5), 446447. doi: 10.1053/ejvs.1998.0796

[24] Zaiko, M. N., Byts, Yu. V., \& Kryshtal, N. V. (2017). Пamoфрізіологія: підручник [Pathophysiology: a textbook]. К.: Meдицина, 2017 - К.: Medicine, 2017. 